\title{
Deep Leiomyoma
}

National Cancer Institute

\section{Source}

National Cancer Institute. Deep Leiomyoma. NCI Thesaurus. Code C6512.

A rare benign smooth muscle neoplasm arising from deep tissue. It is characterized by the presence of spindle cells with cigar-shaped nuclei, interlacing fascicles, and a whorled pattern. 